\title{
Influence of vermicompost humic acid on chlorophyll content and acclimatization in banana clone, Enano Guantanamero
}

Marcia Beatriz Moya Fernández1, Esteban Sánchez Chávez², Daniel Cabezas Montero', Andrés Calderín García ${ }^{3}$, Dany Marrero López ${ }^{4}$, Eduardo F. Héctor Ardisana ${ }^{5}$ and Sandra Pérez Álvarez ${ }^{6^{*}}$

\footnotetext{
${ }^{1}$ Universidad Agraria de la Habana (UNAH) "Fructuoso Rodríguez Pérez", Carretera Tapaste y Autopista Nacional, San José de las Lajas, Mayabeque, Cuba.

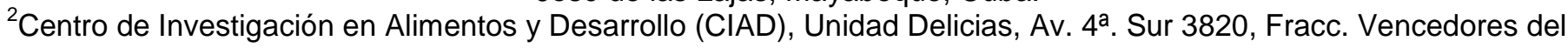
Desierto, Cd. Delicias, Chihuahua. México.

${ }^{3}$ Federal Rural University of Rio de Janeiro, Soil Science Dept. Rodovia BR 465 km 7, Seropédica, RJ, Brazil.

${ }^{4}$ Havana Biofabric, Autopista Nacional Km 23 1⁄2, San José de Las Lajas, Mayabeque, Cuba.

${ }^{5}$ Escuela Superior Politécnica de Chimborazo, Vicerrectorado de Investigación y Posgrado. Panamerican South Km 1 $1 / 2$, Riobamba, Ecuador, C.P. ECO60155.

${ }^{6}$ Instituto Politécnico Nacional, CIIDIR-IPN, Unidad Sinaloa, Departamento de Biotecnología Agrícola, Blvd. Juan de Dios Bátiz Paredes No 250. Guasave, Sinaloa, México, C.P. 81101
}

Received 19 September, 2016; Accepted 11 November, 2016

\begin{abstract}
Vermicompost humic acids (VHA) promote plants' growth because they have similar effects with auxins. The aim of this research was to evaluate the effect of VHA in some physiological indicators in the micropropagation and acclimatization phase of banana clone Enano Guantanamero. Six concentrations were used $\left(0,10,20,30,40\right.$ and $\left.50 \mathrm{mg} \mathrm{L}^{-1}\right)$ to evaluate in vitro the number of leaves, total chlorophyll content and chlorophyll a-b; also in the acclimatization phase, the plant height, stem diameter and number of leaves at three different times (transplant, 25 days and at the end of this phase50 days) were determined. Root length and roots dry weight were evaluated at the end of the acclimatization. VHA applied improved total chlorophyll, chlorophyll a-b at concentrations of 20 and 50 $\mathrm{mg} \mathrm{L}^{-1}$, but not the number of leaves. In the acclimatization stage, plants height at the end of this period (50 days) were higher with $10 \mathrm{mg} \mathrm{L}^{-1}$ (T1) VHA, the number of leaves increased at $40 \mathrm{mg} \mathrm{L}^{-1}$ (T4) and the stem diameter was higher at both concentrations. In the evaluation of roots length, there were no significant differences, but the number of leaves was higher at 10 and $40 \mathrm{mg} \mathrm{L}^{-1}$ (T1 and T4) and it decreased at $50 \mathrm{mg} \mathrm{L}^{-1}$ (T5); roots dry weight increased at $40 \mathrm{mg} \mathrm{L}^{-1}$ (T4). VHA promoted chlorophyll content under in vitro conditions, it reduced the period of acclimatization of banana clone Enano Guantanamero, led to a better growth of plants, and it saved time and resources.
\end{abstract}

Key words: Acclimatization, humic acid, in vitro crop, Musa sp.

\section{INTRODUCTION}

The banana (Musa sp.) constitutes the fourth most important staple food commodity of the world, after rice, 
wheat and maize (Hossain, 2014), so it is considered a basic product, exportation, source of employment and income in many developing countries (FAO, 2015). In Cuba from 2013 to 2014, according to FAO (2015), $508,164.00$ tons of bananas were produced with a yield of $92,090.00 \mathrm{~kg} \mathrm{ha}^{-1}$; this crop together with potatoes and rice are priority food for Cuban population (Juárez, 2013). In vitro multiplication of banana crop is an excellent alternative because it allows a fast and massive clonal multiplication, for this reason a number of countries in the world like Israel, France, Australia, many African countries and Cuba are using this technique (Muhammad et al., 2004). In this technique growth regulators are the most expensive medium ingredients although they are required in very small concentrations (Prakash et al., 2002), for this reason, in recent years, there has been a trend to substitute growth regulators traditionally used in plant biotechnology to produce plants via organogenesis, for biological substances, chemical natural derivatives innocuous to the environment, or mixtures of them. This substitution, as well as being an alternative to the use of growth regulators, contributes to the reduction of production costs (Héctor et al., 2007).

In Cuba, several bioactive products are used for this partial or total substitution of growth regulators, such as Pectimorf, Biobras-16, FitoMAS-E, with the aim to improve growth indicators of in vitro cultured plants, and also in field conditions (Terry-Alfonso et al., 2014). During the last decade, the use of humic substances (HS) as growth indicator has increased as they have favorable effects on plant growth, especially in the proliferation of roots (Canellas et al., 2002; Trevisan et al., 2010).

The HS, considered as natural polymers, represent up to $90 \%$ of organic matter present in soils. They are used as bio-stimulators for plants growth and development because they have effect on the chemical, physicochemical and biological properties of soils (Muscolo et al., 2007). Due to their high availability, agriculture-derived vermicomposts (agro-materials) are excellent raw materials for obtaining HS (Calderín et al., 2012).

The VHA are used in the present research, due to their stimulatory effects known as "like-auxin" analogous to plant hormones presents in plants (Muscolo et al., 2007), so the aim of this work was to evaluate the effect of different VHA concentrations on physiological indicators during micropropagation and acclimatization phase of the banana clone Enano Guantanamero.

\section{MATERIALS AND METHODS}

This research was done from June 2012 to September 2013 at the
Havana Bio-factory and the Chemistry Laboratory of the Agrarian University of Havana (UNAH), Cuba.

Plant materials for the determination of physiological indicators (number of leaves, photosynthetic pigments, plant height, stem diameter) were explants of banana (Musa sp.) clone Enano Guantanamero (viand type).

\section{Chemical-physical characterization of vermicompost humic acids}

As a starting substrate, cattle manure vermicompost with three months of maturation was used. For vermicompost process, the cattle used was fed mainly with grasses, and the manure was processed with African red worm. This vermicompost was used for the humic substances extraction according to International humic substances society (2008) with $\mathrm{NaOH}\left(0.1 \mathrm{~mol} \mathrm{~L}^{-1}\right)$ in a proportion of 1:10 ( $\mathrm{mg}$ of vermicompost: $\mathrm{mL}$ dissolution) and shaking in a MR1 Mini rocker shaker (BOECO, Germany), for $8 \mathrm{~h}$. Humic acids (HA) were precipitated with $\mathrm{HCl}\left(0.01 \mathrm{~mol} \mathrm{~L}^{-1}\right)$ and then centrifuged and finally they were purified with $\mathrm{HCl}: \mathrm{HF}: \mathrm{H}_{2} \mathrm{O}$ in a proportion of $1: 1: 98$ $(\mathrm{mL})$.

The VHA were structurally modified with acetic anhydride and thionyl chloride according to the techniques described by Andjelkovic et al. (2006), for obtaining the derivatives: acetylated $\mathrm{AH}(\mathrm{AH}-\mathrm{Ac})$ and $\mathrm{AH}$ methylated (AH-Met). For ammonia derivative, $30 \mathrm{~mL}$ of $\mathrm{NH}_{4} \mathrm{OH}(7.5 \%)$ and $500 \mathrm{mg}$ of $\mathrm{HA}$ were used in a reflow equipment and magnetic stirrer at $45^{\circ} \mathrm{C}$ for $1 \mathrm{~h}$. The product obtained $\left(\mathrm{AH}-\mathrm{NH}_{3}\right)$ was washed previously, centrifuged and dried at $50^{\circ} \mathrm{C}$.

The percentage of carbon in the HAs and their derivatives were determined by Tyurin method (Nikitin, 1972). The E4/E6 rate was obtained by the relation between absorbance values at 465 and $665 \mathrm{~nm}$ in a RayLight Spectrophotometer UV2100 [ultravioletvisible spectroscopy (UV-vis)]. The inclination parameters were obtained with the following formulation:

$\mathrm{E} 4$
Inclination $=-6.435 \log (-)$
$\mathrm{E} 6$

Where, E4 is value of curve inclination at $465 \mathrm{~nm}$ and E6 is value of curve inclination at $665 \mathrm{~nm}$.

The total acidity, the acidity of $-\mathrm{COOH}$ groups and $-\mathrm{OH}$ groups produced were also calculated, using the procedure described by Canellas et al. (2008a)

The chemical-physical characterization of the main groups presents in the HAs and their derivatives were realized with diffuse reflectance fourier-transformed infrared (DRIFT) (Baes and Bloom, 1989) and chemically by ultraviolet-visible spectroscopy (UV-VIS) (Canellas et al., 2000). Spectral DRIFT was registered in a PE Spectrum-one, obtaining the individual spectra in the frequency range of 700 to $4000 \mathrm{~cm}^{-1}$ with a resolution of $4 \mathrm{~cm}^{-1}$.

The spectral UV-vis was obtained with a $10 \mathrm{mg}$ of VHA dissolved in $100 \mathrm{~mL}$ of distilled water, with a wavelength from 200 to $800 \mathrm{~nm}$.

\section{In vitro parameters}

\section{Number of leaves}

The number of leaves was determined by counting and it was 


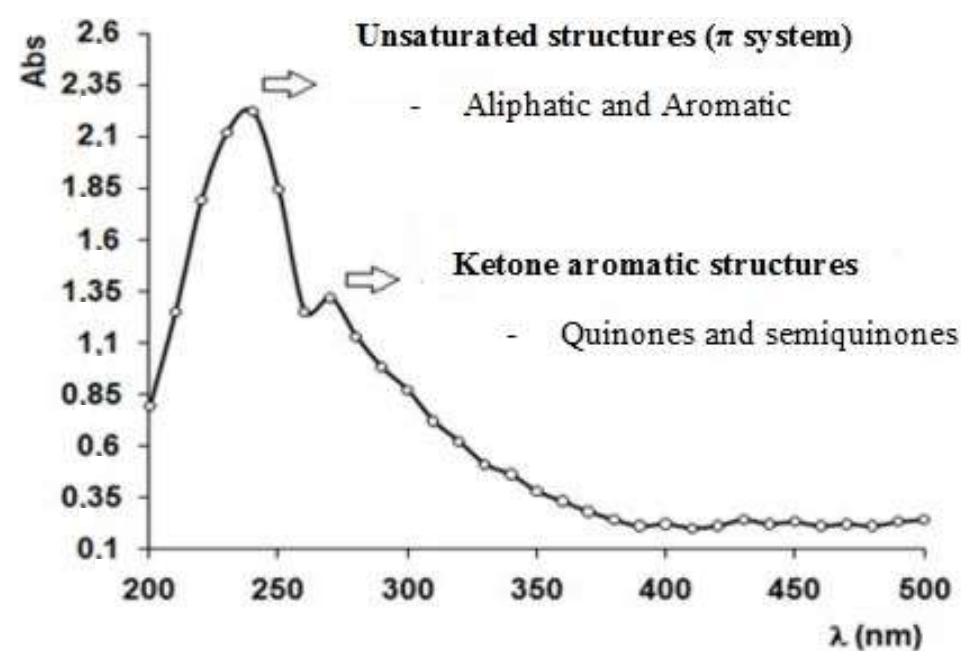

Figure 1. UV-vis spectrum of VHA used in experiments.

expressed as a statistical average (standard error) for each concentration used.

\section{Determination of photosynthetic pigments content}

In vitro plants came from four subcultures (multiplication phase) micropropagated in Murashige and Skoog (MS) (1962) medium at Havana Biofabric, under controlled conditions. Different concentrations of VHA were used in the MS medium $(0,10,20,30$, 40 and $50 \mathrm{mg} \mathrm{L}^{-1}$ ).

The photosynthetic pigments were determined according to the method of Lichtenthaler (1987), using $1.5 \mathrm{~g}$ of macerated green leaves with $25 \mathrm{~mL}$ of $45 \%$ acetone. The mixture was incubated for 1 $h$ at $40^{\circ} \mathrm{C}$ in a thermostat bath (DC-3006), and then pure acetone was added to stop the reaction. The mixture was vacuum-filtered and saturated $\mathrm{NaCl}$ and $\mathrm{NH}_{4} \mathrm{OH}\left(0.02 \mathrm{~mol} \mathrm{~L}^{-1}\right)$ were added; then it was shaken and separated in a funnel with petroleum ether $(50-$ $60^{\circ} \mathrm{C}$ ). In the ether phase (upper phase) were the chlorophylls. The absorbance was determined in a spectrophotometer (RayLinght UV-2100) at wavelengths of $\lambda 645$ and $663 \mathrm{~nm}$. The chlorophylls content was calculated using the following equations:

1. Total chlorophylls $=8.02($ Abs. $\lambda 663 \mathrm{~nm})+20.21($ Abs. $\lambda 645 \mathrm{~nm})$

2. Chlorophyll $a=12.7$ (Abs. $\lambda 663 \mathrm{~nm})-2.69$ (Abs. $\lambda 645 \mathrm{~nm})$

3. Chlorophyll $b=22.9$ (Abs. $\lambda 645 \mathrm{~nm}$ ) - 4.68 (Abs. $\lambda 663 \mathrm{~nm}$ )

\section{Acclimatization}

After four subcultures in vitro plants were removed from the medium, they were washed carefully with common water and transplanted in trays with 70 holes, filled with a mix of organic matter, earthworm humus and Trichoderma harzianum in a proportion of 50:40:10 (g). The plants were grown in a greenhouse for 50 days. Evaluation was done thrice, first one during transplantation just before VHA application, the second one after 25 days (second application of VHA) and the last one at 50th day (culmination of the acclimatization phase). The VHA was sprayed to wet all the aerial parts of the plant. Different concentrations of VHA were used $\left(0,10,20,30,40\right.$ and $\left.50 \mathrm{mg} \mathrm{L}^{-1}\right)$.

The parameters evaluated were: plant height $(\mathrm{cm})$, stem diameter $(\mathrm{mm})$ and number of leaves. At the end of the acclimatization stage, root length $(\mathrm{cm})$ and roots dry weight were also evaluated. Samples were dried at $105^{\circ} \mathrm{C}$ for $1 \mathrm{~h}$ in a drier (Venticell Medcenter). The biomass was determined in analytical balance (Sartorius, $E= \pm$ $0.0001 \mathrm{~g}$ ) and the process was repeated until a constant biomass was obtained. The results were expressed in milligrams (mg).

\section{Statistical analysis}

The experimental design was randomized with six levels of VHA (0, $10,20,30,40$ and $50 \mathrm{mg} \mathrm{L}^{-1}$ ) and 20 plants for each concentration. All experiments were performed in triplicate $(60$ plants in total for each concentration). The statistical analyses consisted of a simple ANOVA (analysis of variance). Tukey's multiple-comparison test was performed when a studied factor showed significance. For these tests, the statistical program STATGRAPH (v. 5.1 plus) was used.

\section{RESULTS}

\section{Chemical-physical characterization of vermicompost humic acids}

Figure 1 shows the UV-vis spectrum of the VHA obtained. A decrease of absorption with increasing wavelength was observed. An intense peak at shorter wavelengths (200 $250 \mathrm{~nm}$ ) was observed in the spectrum. This can be assigned to structures with unsaturated bonds, which are responsible for the high light absorption. Important conjugated instaurations mainly with aromatic nature can be visualized as an intense peak, indicating a high presence of these structures. The UV-vis spectra information allows one to infer in a preliminary way that this VHA has an elevated degree of condensation and aromaticity, as its source of origin is a vermicomposting process.

A shorter peak close to $280 \mathrm{~nm}$ was also visualized in the UV-vis spectra because of the presence of quinone structures which are characteristic of these systems (HA). The elemental composition and some chemical 
Table 1. Elemental composition, functional groups content, atomic relations and $E_{4} / E_{6}$ of the VHA used in experiments.

\begin{tabular}{cccccccccccc}
\hline $\mathbf{C}(\%)$ & $\mathbf{H}(\%)$ & $\mathbf{O}(\%)$ & $\mathbf{N}(\%)$ & $\mathbf{S}(\%)$ & $\mathbf{H} / \mathbf{C}$ & $\mathbf{O} / \mathbf{C}$ & $\mathbf{C} / \mathbf{N}$ & $\begin{array}{c}\text { Carboxyl } \\
\left(\mathrm{mol} \mathrm{kg}^{-1}\right)\end{array}$ & $\begin{array}{c}\text { Phenol } \\
\left(\mathrm{mol} \mathrm{kg}^{-1}\right)\end{array}$ & $\begin{array}{c}\text { Total acidity } \\
\left(\mathrm{mol} \mathrm{kg}^{-1}\right)\end{array}$ & $\mathbf{E 4 / E 6}$ \\
\hline 56.7 & 4.84 & 34.6 & 3.07 & 0.72 & 0.08 & 0.61 & 18.4 & 9.24 & 2.03 & 11.27 & 4.22 \\
\hline
\end{tabular}

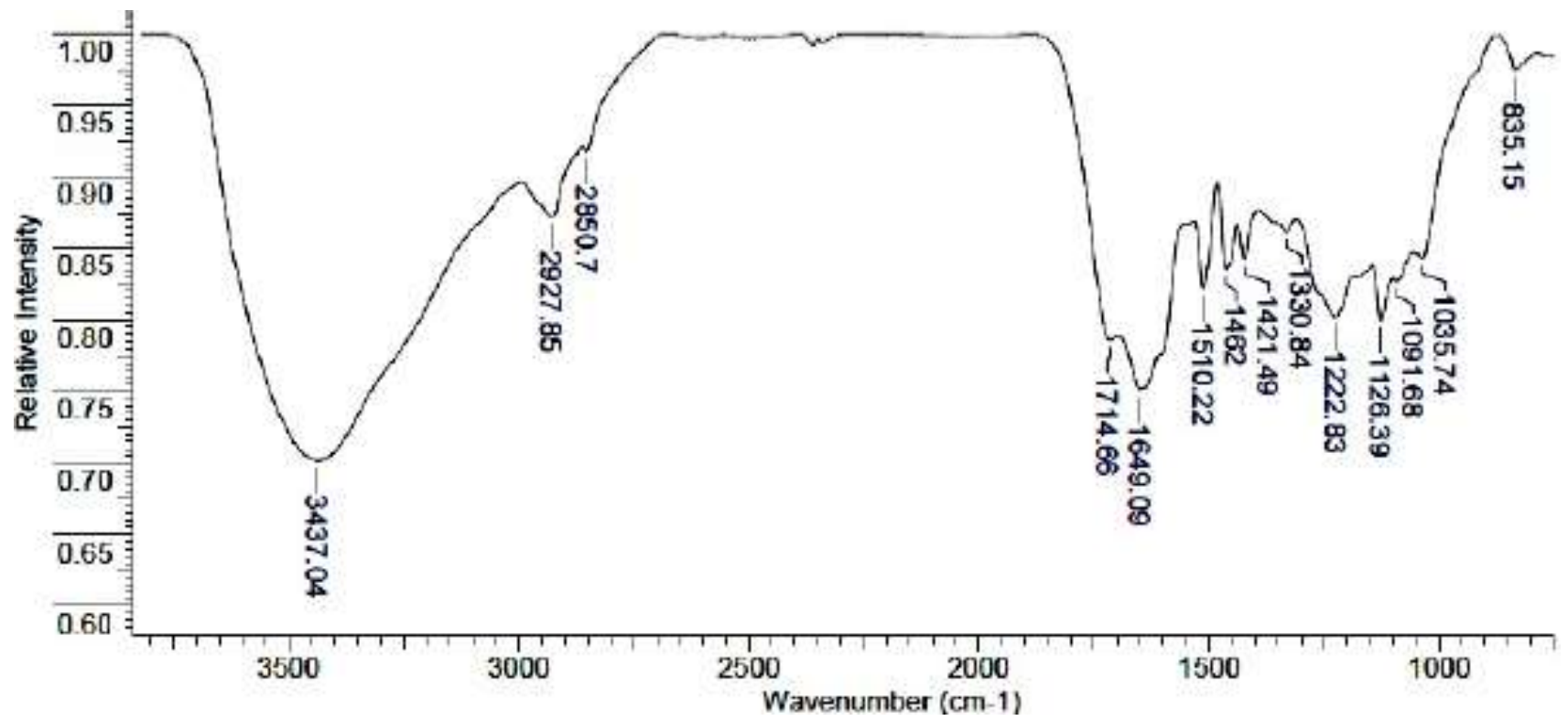

Figure 2. DRIFT spectrum of VHA used in experiments. Bands assignments were according to Piccolo (2002).

properties of VHA are shown in Table 1. The E4/E6 parameter (relation between extinction coefficients at 465 and $665 \mathrm{~nm}$ ) was also calculated. For this VHA the value was 4.22 which is similar to the value established for humic substances that came from composted source, which must be below the value of 6 .

In Figure 2a wide band of $3437.04 \mathrm{~cm}^{-1}$ was observed, associated with inter and intramolecular hydrogen. The extend $\mathrm{NH}$-amide also contributed to this peak.

The bands 2927.85 and $2850.7 \mathrm{~cm}^{-1}$ are associated with the wide $\mathrm{CH}$ aliphatic symmetric and asymmetric, in which the band $1714.66 \mathrm{~cm}^{-1}$ can be associated with the wide $\mathrm{C}=\mathrm{O}$ from aldehydes and ketones. The band $1649.09 \mathrm{~cm}^{-1}$ is also because the wide $\mathrm{C}=\mathrm{O}$ but from quinones and amides. Characteristics bands of $\mathrm{C}=\mathrm{C}$ and $\mathrm{C}=\mathrm{N}$ that are narrow, with aromatics and amides structures, and $\mathrm{CN}$ deformation were present at 1510.22 and $1462 \mathrm{~cm}^{-1}$. The band at $1421.49 \mathrm{~cm}^{-1}$ was a deformation $\mathrm{CH}_{2}$ zone corresponding to $\mathrm{OH}$ of carbonyl groups and the wide $\mathrm{C}=\mathrm{O}$ of phenols. Also, the bands 1222.83 and $1126.39 \mathrm{~cm}^{-1}$ can be attributed to $\mathrm{C}=\mathrm{O}, \mathrm{OH}$ deformation of carboxylic acids and to a $\mathrm{CO}$ of phenols and esters. The bands observed at 1091.68 and 1035.74 $\mathrm{cm}^{-1}$ can be assigned to $\mathrm{CO}$ of esters groups and the rest of the polysaccharides.

\section{In vitro parameters}

\section{Number of leaves}

The number of leaves was evaluated in explants of banana clone: Enano Guantanamero (Figure 3). There were no significant differences between the $0 \mathrm{mg} \mathrm{L}^{-1}$ and the other concentrations used, except for $20 \mathrm{mg} \mathrm{L}^{-1}$ that was lower than the control and the concentration of 50 $\mathrm{mg} \mathrm{L}^{-1}$.

\section{Determination of photosynthetic pigments content}

The total chlorophyll, chlorophyll $a$ and $b$ are shown in Table 2. The study showed that VHA at 20 and $50 \mathrm{mg} \mathrm{L}^{-1}$ induced the higher concentrations for photosynthetic pigments.

\section{Acclimatization}

The physiological indicators at this phase were determined thrice according to the application of the VHA. The plant height during transplantation was higher in the control and in $10 \mathrm{mg} \mathrm{L}^{-1}$ of VHA. This result is the 




Figure 3. Number of leaves in vitro with VHA in MS medium of banana clone: Enano Guantanamero). Different letters indicate significant differences according to Tukey's test, $p \leq 0.05$ ). Bars represent averages \pm standard error (SE) from three replicate experiments.

Table 2. Photosynthetic pigments content in explants of banana clone Enano Guantanamero with VHA in the MS medium.

\begin{tabular}{lccc}
\hline Concentrations of VHA & Total chlorophyll $\left(\mathbf{m g ~ g}^{-1} \mathbf{F W}\right)$ & Chlorophyll a $\left(\mathbf{m g ~ g}^{-1} \mathbf{F W}\right)$ & Chlorophyll b $\left(\mathbf{m g ~ g}^{-1} \mathbf{F W}\right)$ \\
\hline Control & $0.206^{\mathrm{d}}$ & $0.083^{\mathrm{c}}$ & $0.123^{\mathrm{c}}$ \\
T1 $\left(10 \mathrm{mg} \mathrm{L}^{-1} \mathrm{VHA}\right)$ & $0.202^{\mathrm{e}}$ & $0.0422^{\mathrm{e}}$ & $0.160^{\mathrm{d}}$ \\
T2 $\left(20 \mathrm{mg} \mathrm{L} \mathrm{VHA}^{-1}\right)$ & $0.54^{\mathrm{a}}$ & $0.162^{\mathrm{b}}$ & $0.378^{\mathrm{a}}$ \\
T3 $\left(30 \mathrm{mg} \mathrm{L}^{-1} \mathrm{VHA}\right)$ & $0.290^{\mathrm{c}}$ & $0.060^{\mathrm{d}}$ & $0.109^{\mathrm{c}}$ \\
T4 $\left(40 \mathrm{mg} \mathrm{L}^{-1} \mathrm{VHA}\right)$ & $0.198^{\mathrm{f}}$ & $0.038^{\mathrm{f}}$ & $0.127^{\mathrm{c}}$ \\
T5 $\left(50 \mathrm{mg} \mathrm{L}^{-1} \mathrm{VHA}\right)$ & $0.544^{\mathrm{a}}$ & $0.203^{\mathrm{a}}$ & $0.341^{\mathrm{b}}$ \\
\hline
\end{tabular}

Different letters indicate significant differences $(p \leq 0.05)$.

remaining effect from the in vitro phase. After VHA was applied for the second time (25 days) plant height increased by $200 \%$ (from 7.7 to $16.64 \mathrm{~cm}$ ) with $10 \mathrm{mg} \mathrm{L}^{-1}$. Finally, at the end of the acclimatization period, this parameter increased by $346 \%$ (from 7.7 to $26.66 \mathrm{~cm}$ ) (Figure 4).

For plant height at the acclimatization phase is possible to see that with $10 \mathrm{mg} \mathrm{L}^{-1}$ of VHA plants growth more than with the others concentrations used.

The stem diameter was also determined (Figure 5). At the moment of the transplant not significant differences were found for the stem diameter between 0,10 and 50 $\mathrm{mg} \mathrm{L}^{-1}$, but at the end of the acclimatization the diameter increased in 328 and $354 \%$ with 10 and $40 \mathrm{mg} \mathrm{L}^{-1}$ respectively.

The number of leaves was counted for the different concentrations used as is possible (Figure 6).

The number of leaves at the end of the acclimatization with $40 \mathrm{mg} \mathrm{L}^{-1}$ increased in $151 \%$. Plants without VHA showed a decrease in this important physiological parameter.

Roots length and dry weight are shown in Figure 7.

The roots length did not show any significant differences between the concentrations of VHA used, in the other hand the dry weight of this organ was higher and significant differences were found for $40 \mathrm{mg} \mathrm{L}^{-1}$ of VHA, being this concentration higher to the control in $205 \%$.

\section{DISCUSSION}

Vermicompost is a very useful growth medium for most crops because of high content of many available nutrients and plant growth promoters (Arancon et al., 2004). According to Ricci et al. (1995) vermicompost provides P, $\mathrm{Ca}, \mathrm{Mg}$, and $\mathrm{S}$ like inorganic fertilizers. Additionally, Arancon et al. (2004) showed that vermicompost 

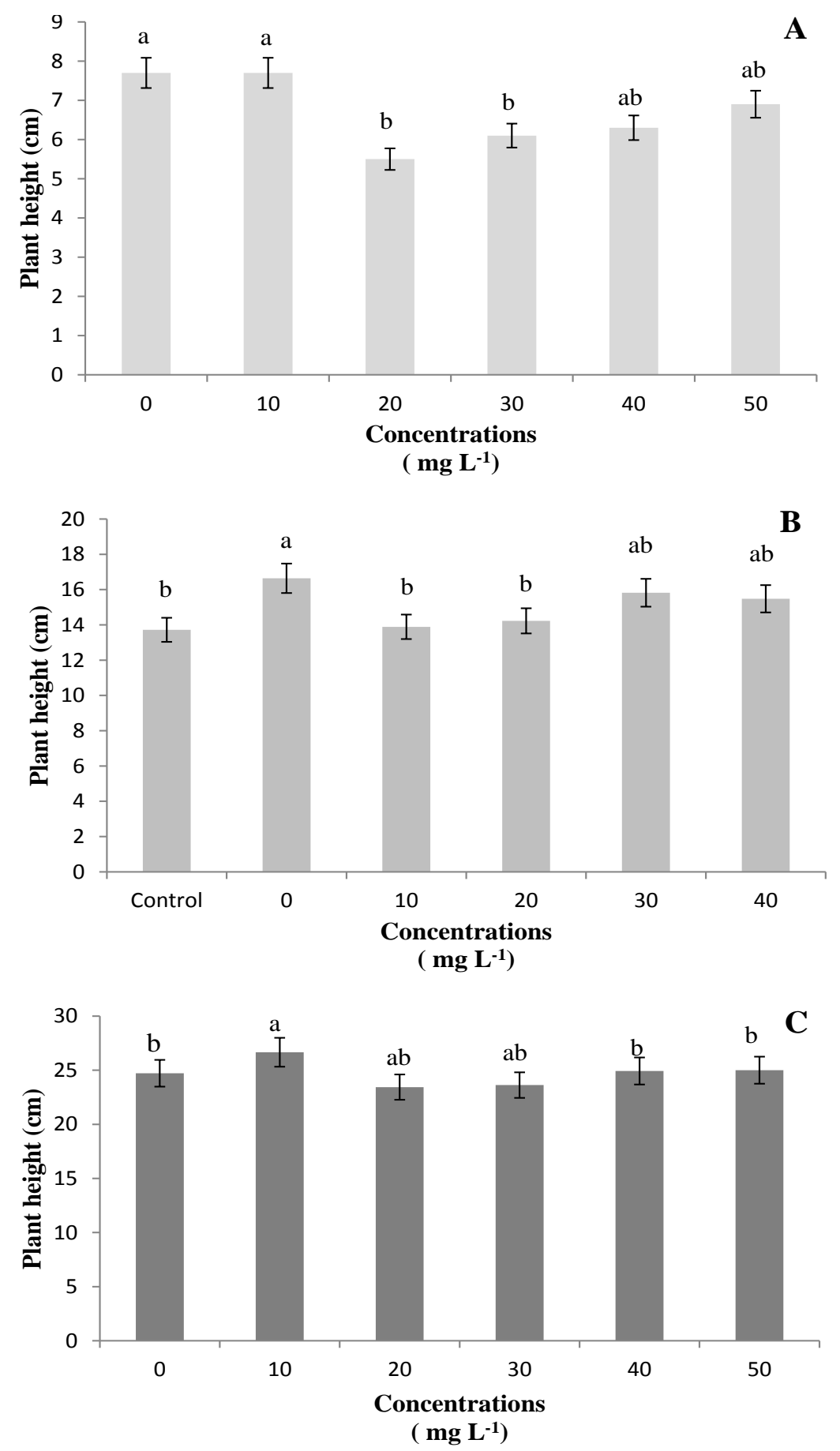

Figure 4. Plant height $(\mathrm{cm})$ at acclimatization phase of banana clones Enano Guantanamero. A. During transplantation before VHA application. B. After 25 days of transplantation, second application of VHA. C. End of the acclimatization process (50 days). Different letters indicate significant differences according to Tukey's test, $p \leq 0.05)$. Bars represent averages \pm standard error (SE) from three replicate experiments.

enriched with HS could promote plant growth and nutrient uptake, but it is necessary that this product has good qualities, like the quantities of the diverse elements and relative percentage of the phenolic and carboxylic acids (Table 1) that are similar to the range reported by the International Humic Substances Society (Ritchie and 

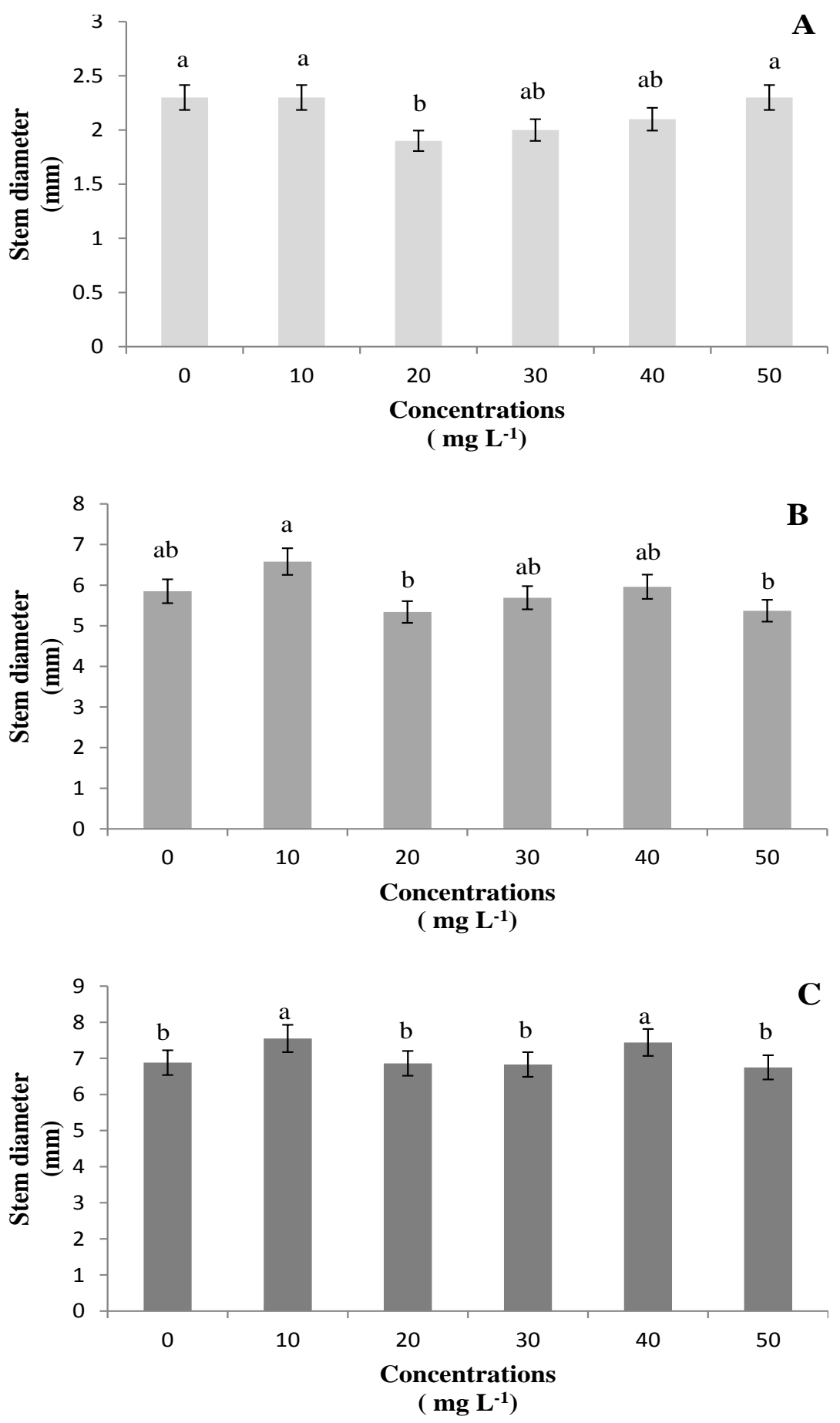

Figure 5. Stem diameter $(\mathrm{mm})$ at acclimatization phase of banana clone Enano Guantanamero. A. During transplantation before VHA application. B. After 25 days of transplantation, second application of VHA. C. End of the acclimatization process (50 days). Different letters indicate significant differences according to Tukey's test, $p \leq 0.05)$. Bars represent averages \pm standard error (SE) from three replicate experiments.

Purdue,2003). Also, the rate E4/E6 was 4.22 , indicating that the VHA obtained had a great humidification and maturity degree, properties derived from its high degree of condensation and aromaticity. This result is similar to that obtained by Campitelli and Ceppi (2008) and Fukushima et al. (2009). The VHA from soils with little air 

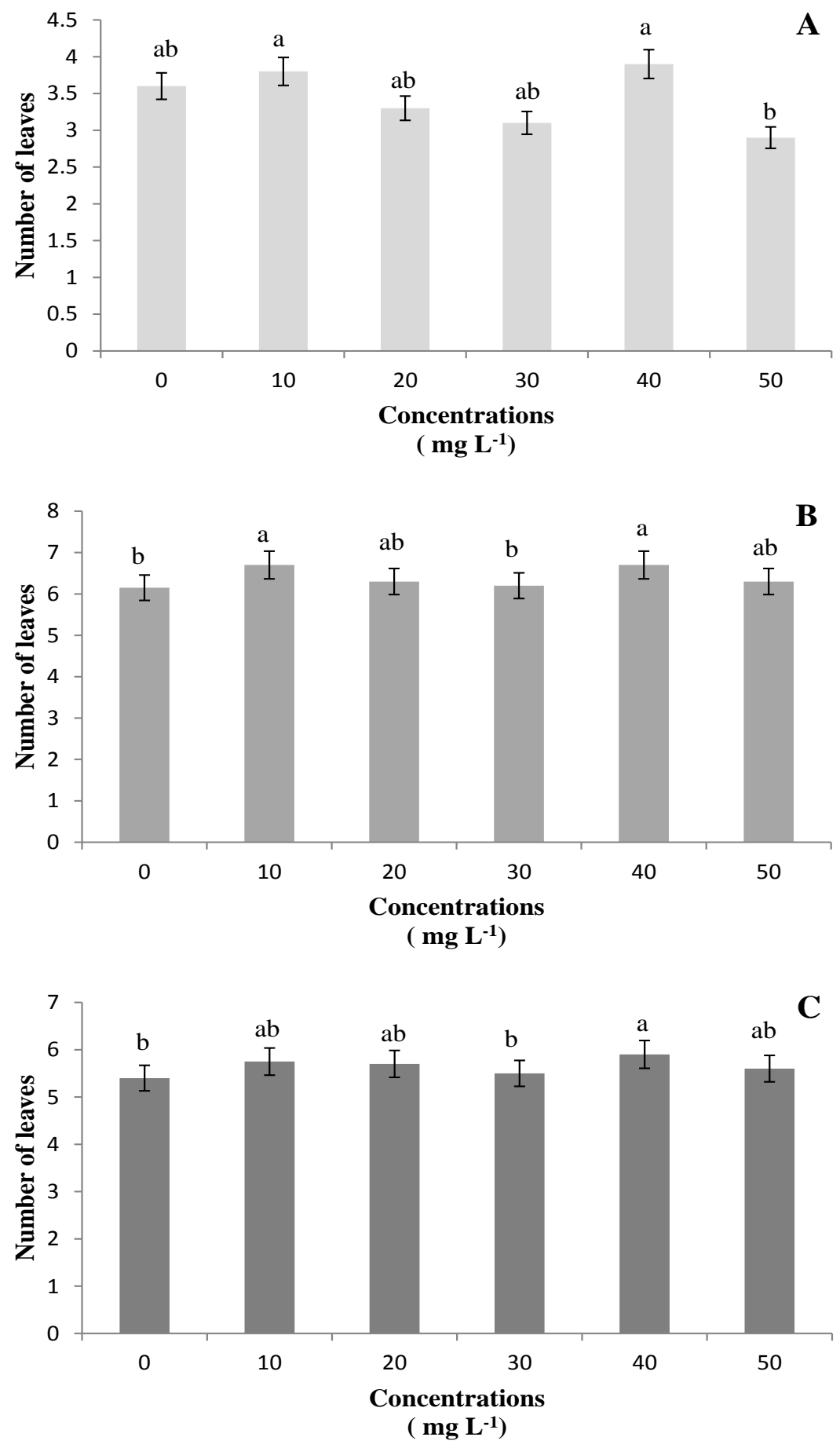

Figure 6. Numbers of leaves at acclimatization phase of banana clone Enano Guantanamero. A: During transplantation before VHA application; B: After 25 days of transplantation, second application of $\mathrm{VHA}$; C: End of the acclimatization process (50 days). Different letters indicate significant differences according to Tukey's test, $p \leq 0.05$ ). Bars represent averages \pm standard error (SE) from three replicate experiments.

has a higher content of condensed structures due to the elevated rate $E 4 / E 6$, high fluorescence intensity and more free radicals (Canellas et al., 2008b).
To make the allocations to the main absorption peaks related to the reactions involved in the DRIFT, spectra obtained were taken into account in respect to those 

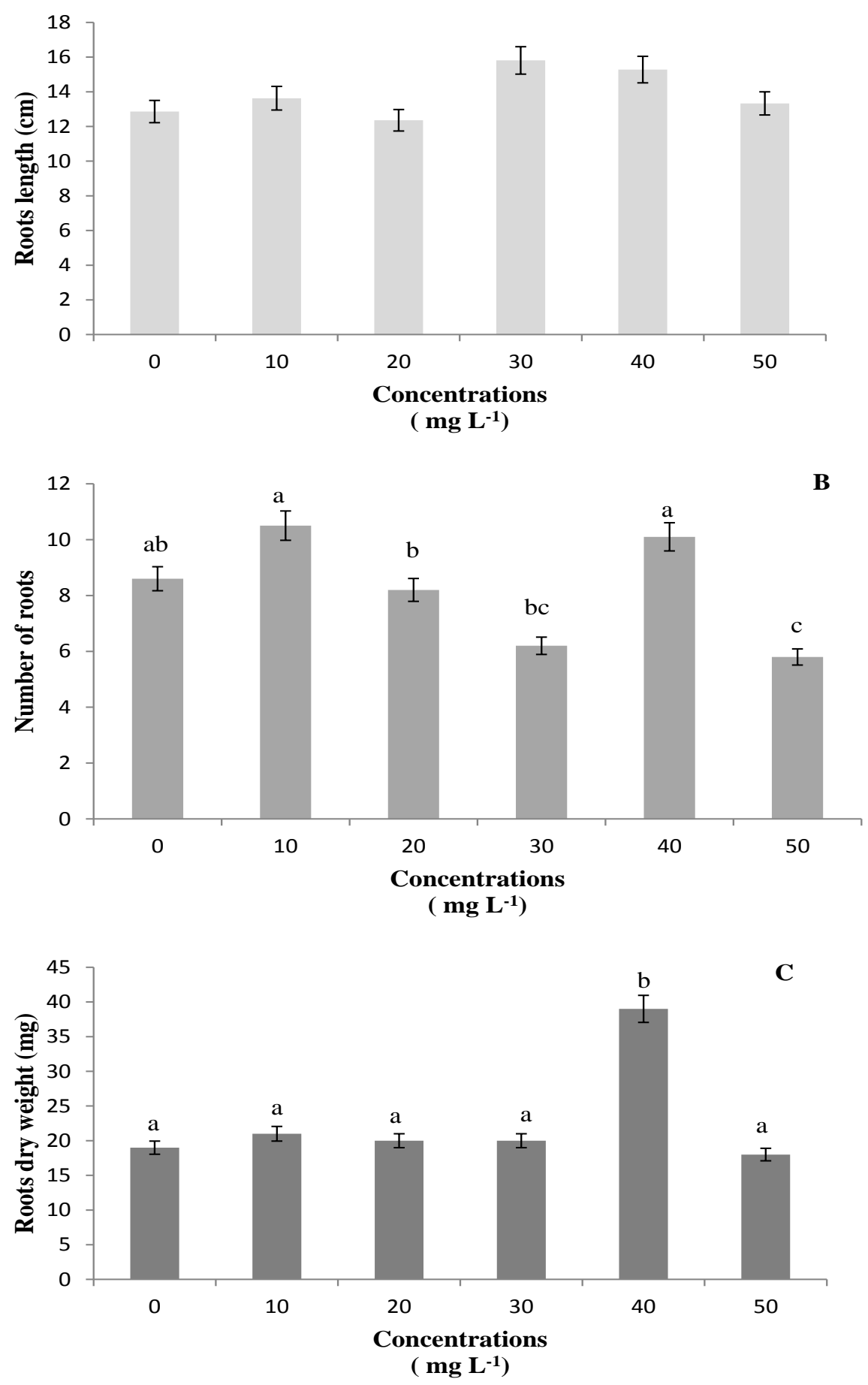

Figure 7. Roots evaluation at acclimatization phase of banana clone Enano Guantanamero. A. Root length. B. Number of roots. C. Roots dry weight. Different letters indicate significant differences according to Tukey's test, $p \leq 0.05$ ). Bars represent averages \pm standard error (SE) from three replicate experiments.

reported in the specialized literature and research presented by Chen et al. (2009), Dobbss et al. (2009), Spaccini and Piccolo (2009).

All the parameters analyzed in the VHA used in this research demonstrated the great qualities of the product used, this studies had a great importance in understanding their modes of action and practical use (Muscolo et al., 2013).

In vitro, some parameters were determined to evaluate the influence of VHA in the explant of banana clone 
Enano Guantanamero. VHA had no influence over the number of leaves in this crop. Many authors report the increases in plant growth including number of leaves when VHA is used such as da Silva et al. (2015) in Cattleya warneri (Orchidaceae), Atiyeh et al. (2002) in tomato (Solanum lycopersicum L.) and some species from Cucurbitaceae family, Moghadam et al. (2012) in Lilium Asiatic hybrid var. Navona, and some others.

The evaluation of total chlorophyll and chlorophylls a and $b$ showed an increase in the photosynthetic pigments due to VHA influence, but not in all concentrations used.

According to Nardi et al. (2002), the principal effect of HS in the photosynthetic process is not clear yet, but the application of these substances induces an increase in chlorophyll. This does not mean a direct relation with photosynthesis and finally with plant production. It seems that the effects of HS on plants may be selective and variable, depending on their concentration and $\mathrm{pH}$ of medium (Nardi et al., 2002), as seen in this research where the effect on photosynthetic pigments depended on VHA concentration. Elevated concentration of $\mathrm{HS}$ $(100,200$ and $400 \mathrm{ppm})$ decreased chlorophyll content (Cooper et al., 1998) but in this work, low and intermediated concentration induced reduction in chlorophyll content.

It has been reported that the effect of humified materials on the stimulation of pigment contents depends on the physiological state of plants and the concentrations of the material. In a research on Phaseolus vulgaris L., with foliar application of humates extracted from vermicompost, it was found that chlorophyll content could be stimulated or inhibited (Portuondo et al., 2009); and in this investigation with banana in vitro, the chlorophyll content was stimulated by different concentrations of VHA.

The acclimatization phase normally for banana is from 60 to 90 days (Granada, 1990), but with the application of VHA this phase was reduced to 50 days for banana clone Enano Guantanamero with an increase in plant height, stem diameter and number of leaves compared with the control.

At the end of the acclimatization $10 \mathrm{mg} \mathrm{L}^{-1}$ was the VHA concentration recommended for plant height and stem diameter and $40 \mathrm{mg} \mathrm{L}^{-1}$ stimulated number of leaves, stem diameter and roots dry weight. All the parameters evaluated decreased without VHA $\left(0 \mathrm{mg} \mathrm{L}^{-1}\right)$ and with the higher concentration $\left(50 \mathrm{mg} \mathrm{L}^{-1}\right)$. According to Singh and Chauhan (2009) applied vermicompost to French bean (Phaseolus vulgaris L.) plants induced an increase in several parameters such as germination, height of plant, number of leaves per plant, length of leaves, width of leaves, and so, due to vermicompost treatments improve physico-chemical properties of soil.

In groundnut (Arachis hypogaea L.) vermicompost concentrations were used $(0,100,150,200$ and $250 \mathrm{mg}$ $\mathrm{L}^{-1}$ ) to evaluate different parameters where the highest root length, shoot length, total leaf area, number of root nodules, fresh weight, dry weight, chlorophyll and carotenoids were recorded with application of $200 \mathrm{~g}$ of VHA at various stages of its growth $(25,50,75$ and 100 days) according to Mathivanan et al. (2012).

Hernández et al. (2012) with VHA concentration of 34 to $46 \mathrm{mg} \mathrm{L}^{-1}$ in rice (Oryza sativa L.) obtained significant increases (between 30 and $70 \%$ respects to the control) in roots dry weight. In this research in banana with similar concentration $\left(40 \mathrm{mg} \mathrm{L}^{-1}\right)$ an increase of $205 \%$ over the control was obtained, this result is similar to the measured of this parameter in vitro where $40 \mathrm{mg} \mathrm{L}^{-1}$ induced the higher result (Moya et al., 2014).

Several researches have been reported improvement in many physiological parameters with humic acid. In a perennial ryegrass (Lolium perenne L.), HA concentrations were used $\left(0,100,400\right.$ and $\left.1000 \mathrm{mg} \mathrm{L}^{-1}\right)$ to evaluate different parameters where only $100 \mathrm{mg} \mathrm{L}^{-1}$ favored height of the plant, nitrogen content, roots length and surface of roots (Maibodi et al., 2015). On the contrary, when Can et al. (2008) used 0, 100, 500 and $1000 \mathrm{mg} \mathrm{L}^{-1}$ of humic acid in gerbera plant (Gerbera jamesonii L.), the higher concentration used increased root growth. These researches demonstrate that the influence of humic acid or VHA on plant growth is dependent on the concentration used.

\section{Conclusion}

The VHA used in this investigation showed an elevated degree of condensation and aromaticity. In this research the ability of humic substances to improve plant development has been proved. This action was reflected in an enhancement of some physiological indicators in vitro like total chlorophyll, chlorophyll $a-b$, and in the acclimatization phase, such as plant height, stem diameter, number of leaves, number of roots and roots dry weight. Two VHA concentrations (10 and $50 \mathrm{mg} \mathrm{L}^{-1}$ ) increased in vitro indicators, while for the acclimatization stage $40 \mathrm{mg} \mathrm{L}^{-1}$ can be recommended for banana for its positive effects on number of leaves and root development. The use of VHA in the acclimatization period reduced this phase to 50 days, which means saving water, nutrients and earlier delivery of plants to farmers.

\section{Conflicts of interests}

The authors have not declared any conflict of interests.

\section{Abbreviations}

DRIFT, Diffuse reflectance Fourier-transformed infrared; HS, humic substances; MS, Murashige and Skoog; UVVIS, ultraviolet-visible spectroscopy; VHA, vermicompost 
humic acids.

\section{REFERENCES}

Andjelkovic T, Perovic J, Purenovic M, Blagojevic S, Nikolic R, Adnjelkovic D, Bojic A (2006). Spectroscopic and Potentiometric studies on derivatized natural humic acid. Anal. Sci. 22:1553-1558.

Arancon NQ, Edwards CA, Atiyeh R, Metzger JD (2004). Effects of vermicomposts produced from food waste on the growth and yields of greenhouse peppers. Bioresour. Technol. 93:139-144.

Atiyeh RM, Lee S, Edwards CA, Arancon NQ, Metzger JD (2002). The influence of humic acids derived from earthworm-processed organic wastes on plant growth. Bioresour. Technol. 84:7-14.

Baes AU, Bloom PR (1989). Diffuse reflectance and transmission Fourier transform infrared (DRIFT) spectroscopy of humic and fulvic acids. Soil Sci. Soc. Am. J. 53:695-700.

Calderín A, Berbara L, Portuondo L, Guridi F, Hernandez LO, Hernández R, Nora R (2012). Humic acids of vermicompost as an ecological pathway to increase resistance of seedlings to water stress. Afr. J. Biotechnol. 11(13):3125-3134.

Campitelli $P$, Ceppi $S$ (2008). Effects of composting technologies on the chemical and physicochemical properties of humic acids. Geoderma 144:325-333.

Can W, Kafi M, Babalar M, Etemadi N (2008). Effect of humic acid on plant growth, nutrient uptake, and postharvest life of gerbera. J. Plant Nutr. 31(12):2155-2167.

Canellas LP, Lopes FO, Okorokova-Fac anha AL, Rocha AF (2002). Humic acids isolated from earthworm compost enhance root elongation, lateral root emergence, and plasma membrane $\mathrm{H}$ ATPase activity in maize roots. Plant Physiol. 130:1951-1957.

Canellas LP, Santos GA, Moraes AA, Rumjanek VM, Olivares FL (2000). Avaliacao de caracteristicas de acidos humicos de residuos de origem Urbana: I. Metodos espectroscopicos (UV-vis, IV, RMN 13C-CP/MAS) e microscopia eletronica de varredura. Rev. Bras. Cienc. Solo 24:741-750.

Canellas PC, Santos AG, Busato J, Spaccini R, Piccolo A, Martin L (2008a). Bioactivity and chemical characteristic of humic acids from tropical soils. Soil Sci. 173:624-637.

Canellas LP, Teixeira Junior LRL, Dobbss LB, Silva CA, Medici LO, Zandonadi DB, Façanha AR (2008b). Humic acids cross interactions with root and organic acids. Ann. Appl. Biol. 153:157-166.

Chen $\mathrm{H}$, Berndtsson R, Mingguang M, Zhu K (2009). Characterization of insolubilized humic acid and its sorption behaviors. Environ. Geol. 57:1847-1853.

Cooper RJ, Liu C, Fisher DS (1998). Influence of humic substances on rooting and nutrient content of creeping bentgrass. Crop Sci. 38:1639-1644.

da Silva MAC, dos Santos WO, Simoura NT, Tesch JA, Ruas KF, Colodete CM, Tannure FP, Barbirato JO, Ramos AC, Dobbss LB (2015). Vermicompost humic acid stimulates in vitro growth of Cattleya warneri (Orchidaceae) seedlings. Rodriguésia 66(3):759768.

Dobbss BL, Rumjaneck MV, Baldotto AM, Velloso XC, Canellas PL (2009). Caracterizaçao química e espectroscópica de ácidos húmicos e fúlvicos isolados de camada superficial de latossolos brasileiros. Rev. Bras. Cienc. Solo 33(1):51-63.

FAO (2015). 〈en línea〉 Disponible en: http://faostat3.fao.org/browse/area/49/S. Consultado el 2 de septiembre de 2016.

Fukushima M, Yamamoto K, Ootsuka K, Komai T, Aramaki T, Ueda S, Shigekazu H (2009). Effects of the maturity of wood waste compost on the structural features of humic acids. Bioresour. Technol. 100:791-797.

Granada C (1990). Manejo de plantas em invernadero. In. Fundamentos teórico-práctico del cultivo de tejidos vegetales. Rosell C, Villalobos V. Ed. FAO, Roma. pp. 85-88.

Héctor E, Torres A, Algoe S, Cabañas M, López A (2007). Propagación in vitro del plátano macho (Musa sp. AAB) Clon "Sobrino" con lo Bioestimulantes cubanos BB-6 y Biostán como sustituto de los reguladores del crecimiento. Cultivos Tropicales 28(1):13-18.
Hernández R, García A, Portuondo L, Muñiz S, Berbara R, Izquierdo F (2012). Protección antioxidante de los Ácidos Húmicos extraídos de Vermicompost en arroz (Oryza sativa L.) var. IA Cuba 30. Rev. Protección Veg. 27:2.

Hossain MF (2014). A study of banana production in Bangladesh: area, yield and major constraints. ARPN J. Agric. Biol. Sci. 9:206-210

International Humic Substances Society (2008). From Molecular Understanding to Innovative Applications of Humic Substances. In: 14th International Meeting. September 14-19, Russia. pp. 43-47.

Juárez NH (2013). Cambios en la producción y consumo de viandas en Cuba. Revue d'ethnoécologie 3:1-27.

Lichtenthaler H (1987). Chlorophylls and Carotenoids: pigments of biomembranes. Method Enzymol. 148:350-383.

Maibodi NDH, Kafi M, Nikbakht A, Rejali F (2015). Effect of foliar applications of humic acid on growth, visual quality, nutrients content and root parameters of perennial ryegrass (Lolium perenne L.). J. Plant Nutr. 38(2):224-236.

Mathivanan S, Chidambaram Al A, Sundaramoorthy P, Bakiyaraj R (2012). Effect of vermicompost on growth and yield of groundnut (Arachis hypogaea L.). Int. J. Environ. Biol. 2(1):7-11.

Moghadam ARL, Ardebili ZO, Saidi F (2012). Vermicompost induced changes in growth and development of Lilium Asiatic hybrid var. Navona. Afr. J. Agric. Res. 7:2609-2621.

Moya MBF, Cossio-Vargas LE, Cabezas DM, Calderín AG, Marrero DL, Pérez SA (2014). Potentiality of vermicompost humic acids in banana in vitro micropropagation clone: Enano Guantanamero. J. Environ. Sci. Eng. A2:677-685.

Muhammad A, Hussain I, Naqvi SM, Rashid H (2004). Banana plantlet production through tissue culture. Pak. J. Bot. 36:617-620.

Murashige T, Skoog F (1962). A revised medium for rapid growth and bioassays with tobacco tissue culture. Physiol. Plant. 15:473-497.

Muscolo A, Sidari M, Attina E, Francioso O, Tugnoli V, Nardi S (2007). Biological Activity of Humic Substances is related to their Chemical Structure. Soil Sci. Soc. Am. J. 71:75-85.

Muscolo A, Sidari M, Nardi S (2013). Humic substance: relationship between structure and activity. Deeper information suggests univocal findings. J. Geochem. Explor. 129:57-63.

Nardi S, Pizzeghello D, Muscolo A, Vianello A (2002). Physiological effects of humic substances on higher plants. Soil Biol. Biochem. 34:1527-1536.

Nikitin BA (1972) Metody opredelenija soderžanija gumusa $v$ počve. Agrochimija 3:123-125.

Piccolo A (2002). The supramolecular structure of humic substances: A novel understanding of humus chemistry and implications in soil science. Adv. Agron. 75:57-134.

Portuondo FL, Calderín GA, Hernández LO, Guridi IF, Krespky N, Machado TJ (2009). Componentes del metabolismo del nitrógeno en la fase vegetativa del frijol modificados por la aplicación de Ácidos Húmicos. In. Congress Agrociencia.

Prakash S, Hoque MI, Brinks T (2002). Culture media and containers. In. International Atomic Energy Agency (ed.): Low cost options for tissue culture technology in developing countries. Proceedings of a technical meeting, 26-30 August 2002, Vienna, Austria.

Ricci MSF, Casali VW, Cardoso AA, Ruiz HA (1995). Teores de nutrientes em duas cultivares de alface adubadas com composto orgânico. Pesq. Agropec. Bras. 30:1035-1039.

Ritchie JD, Perdue EM (2003). Proton-binding study of standard and reference fulvic acids, humic acids, and natural organic matter Geochim. Cosmochim. Acta 67:85-96.

Silva DS, Bosisio A, Boscarol B, Beltzer A, Amsler GP (1999). Aclimatação de mudas de bananeira (Musa spp.) "Prata"(AAB) em diferentes substratos. Rev. Ceres 46:543-554.

Singh NI, Chauhan JS (2009). Response of French bean (Phaseolus vulgaris L.) to organic manures and inorganic fertilizer on growth and yield parameters under irrigated condition. Nat. Sci. 7(5):52-54.

Spaccini R, Piccolo A (2009). Molecular characteristics of humic acids from compost increasing maturity stages. Soil. Biol. Biochem. 41:1154-1172.

Terry-Alfonso E, Ruiz-Padrón J, Tejeda-Peraza T, Reynaldo-Escobar I, Carrillo-Sosa Y, Morales-Morales HA (2014). Interacción de bioproductos como alternativas para la producción horticultura cubana. Tecnociencia Chihuahua 8(3):163-174. 
Trevisan S, Pizzeghello D, Ruperti B, Francioso O, Sassi A, Palme K, Quaggiotti S, Nardi S (2010). Humic substances induce lateral root formation and expression of the early auxin-responsive IAA19 gene and DR5 synthetic element in Arabidopsis. Plant Biol. 12:604-614. 